\title{
Initial effects of improved drill and blast practices on stope stability at Acacia's Bulyanhulu Mine
}

\author{
GC Chilala Acacia Mining plc, Tanzania \\ J de Assuncao Acacia Mining plc, Tanzania \\ R Harris Acacia Mining plc, Tanzania \\ RM Stephenson AMC Consultants, Australia
}

\begin{abstract}
High levels of stope dilution were experienced in the deeper longhole open stoping mining areas at Bulyanhulu Gold Mine, a narrow vein underground mining operation in Tanzania. Production losses and equipment damage were often associated with large slabs becoming dislodged from stope walls.

One of the major contributing factors causing high dilution was considered to be drill and blast practices applied in different rock types. A preliminary quality assurance and quality control (QA/QC) study was undertaken in order to decrease dilution and improve productivity from stopes, with many of the introduced measures being integrated into standard procedures. The QA/QC study was a collaborative effort between geotechnical engineering, survey, and drill and blast engineering.
\end{abstract}

This paper discusses the QA/QC process, implementation, preliminary outcomes of the study and ongoing improvement.

\section{Introduction}

Bulyanhulu is a narrow-vein gold mine employing longitudinal longhole open stoping. The mining front retreats towards a central pillar for each panel. Sill pillars are left between the mining panels. In most areas, there have been efforts to extract $100 \%$ of the ore in each panel by placing paste backfill before mining adjacent stopes. Nevertheless, in some areas some rib pillars have been left in order to expedite the extraction process. This paper focuses on the areas where rib pillars have been left for stability purposes.

Once all development has been completed, the stope extraction follows a process of mine design survey mark up, QA/QC, drilling and blasting. Initially, the QA/QC process was not adequately defined because there were no drill and blast engineers to keep track of the drilling, timing, and blasting process. An external contractor would supply the explosives and advise the charging and blasting practice to mining personnel. The drill designs were completed by mine planning engineers.

Changes have been made to the existing longhole process. It now includes drill design, drill and blast $\mathrm{QA} / \mathrm{QC}$, survey drill hole monitoring, and stope summary performance. The process is at a preliminary stage.

\subsection{Mine location}

Bulyanhulu is located $45 \mathrm{~km}$ south of Lake Victoria in the Kahama district of Shinyanga region in Tanzania. Road accesses to the mine are from Mwanza, which is $127 \mathrm{~km}$ to the northeast, and $84 \mathrm{~km}$ to the south from Kahama, shown in Figure 1. 


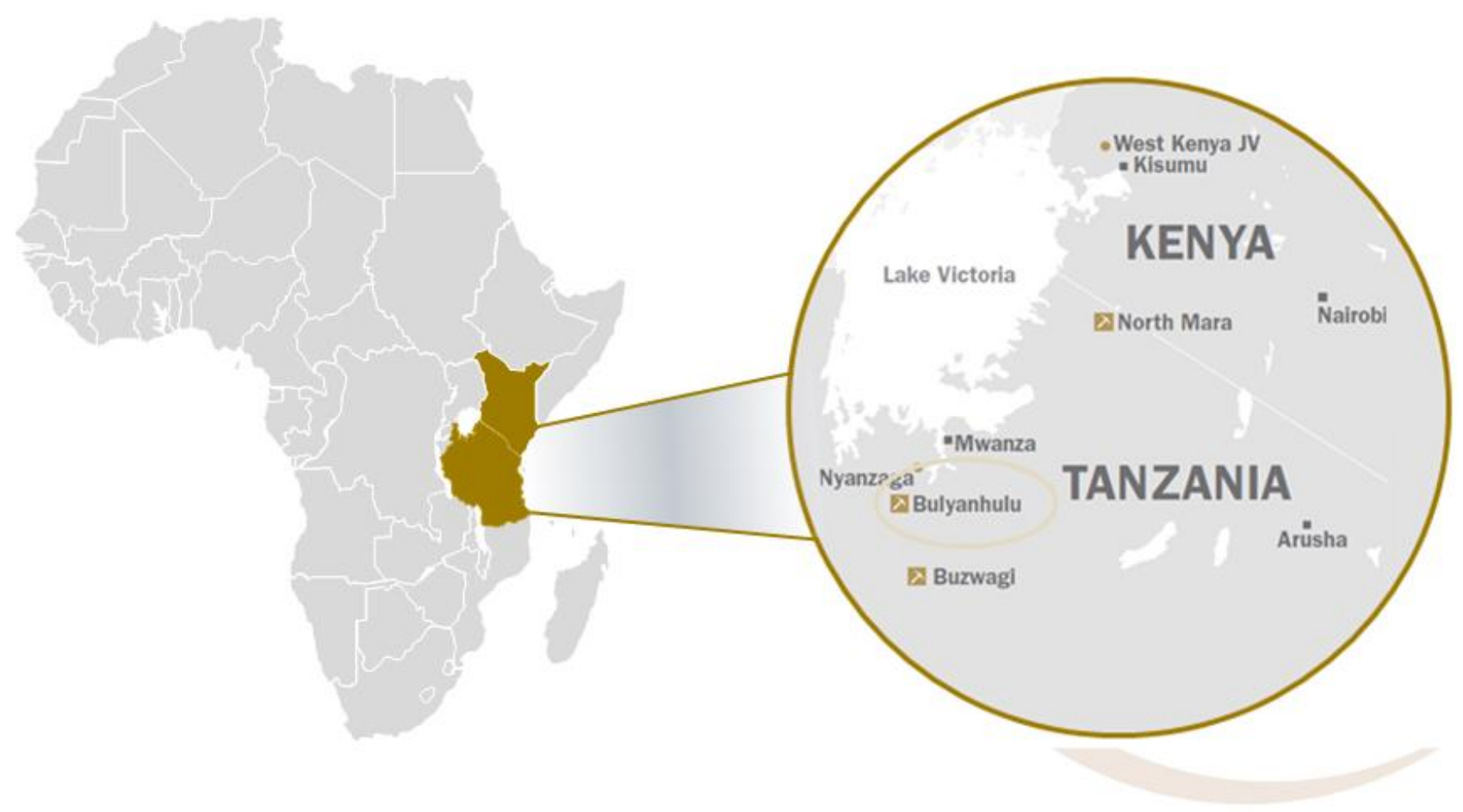

Figure 1 Location of Bulyanhulu

\subsection{Geotechnical setting}

The stratigraphy of Bulyanhulu area is characterised by a volcanic and sedimentary sequence largely consisting of bimodal mafic and felsic extrusive and intrusive rocks intercalated with argillaceous sediments. All units have undergone greenschist-facies metamorphism (Chamberlain 2003).

Mineralisation is hosted within a series of steeply dipping northwest striking quartz reefs generally restricted to sheared argillites and mylonite zones within mafic volcanic units (Figure 2).

The main mineralisation is termed Reef 1 and is hosted by the thickest and most laterally extensive horizon of argillite (domains 1 to 3 in Table 1). The argillite is intensely deformed. The footwall (FW) is mainly comprised of basalt and the hanging wall (HW) is comprised of ash tuff. The main zone of mineralisation is developed at the boundary between the felsic tuffs and basalt. 


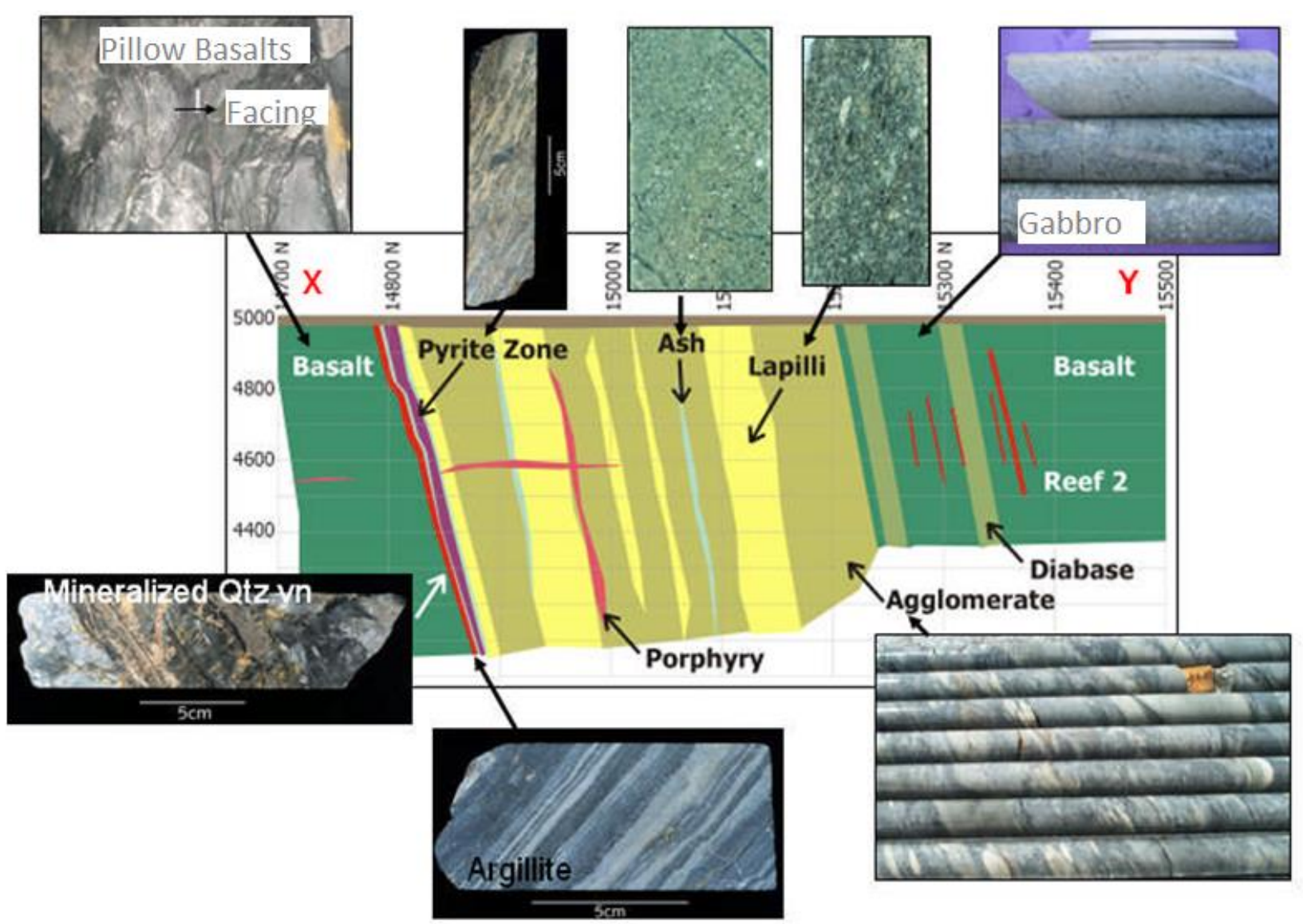

Figure 2 Geology of Bulyanhulu

In order to establish a system that will assist the geotechnical personnel to analyse geotechnical data, a number of domains are defined. The domains are determined using the rock tunnelling quality index, $Q$ (Barton et al. 1974) and the laboratory test results for unconfined compressive strength (UCS). The rock mass parameters of the geotechnical domains are shown in Table 1. Two failure criterions are used: the Hoek-Brown and Mohr-Coulomb. 
Table 1 Geomechanical properties of geotechnical domains at Bulyanhulu

\begin{tabular}{|c|c|c|c|c|c|c|c|c|c|c|c|c|c|c|c|c|}
\hline $\begin{array}{l}\text { Domain } \\
\text { name }\end{array}$ & Rock type & $\begin{array}{l}\text { Typical Q } \\
\text { (median) }\end{array}$ & $\begin{array}{l}\text { UCS } \\
\text { (MPa) }\end{array}$ & $\begin{array}{c}\rho \\
\left(\mathrm{kg} / \mathrm{m}^{3}\right)\end{array}$ & $\begin{array}{c}E_{i} \\
(\mathrm{MPa})\end{array}$ & $\mathrm{m}_{\mathrm{i}}$ & $\begin{array}{c}\sigma_{\mathrm{ti}} \\
(\mathrm{MPa})\end{array}$ & GSI & $m_{b}$ & s & a & $\begin{array}{l}E_{r m} \\
(G P a)\end{array}$ & $\begin{array}{c}\sigma_{\mathrm{crm}} \\
(\mathrm{MPa})\end{array}$ & $\begin{array}{c}\sigma_{\text {trm }} \\
(\mathrm{MPa})\end{array}$ & $\begin{array}{l}\Phi \\
\left({ }^{\circ}\right)\end{array}$ & $\begin{array}{c}\mathrm{c} \\
(\mathrm{MPa})\end{array}$ \\
\hline $\begin{array}{l}\text { Domain } 1 \\
\text { (D1) }\end{array}$ & Sheared argillite & 0.2 & 37 & 2,800 & 54.3 & 6 & -5.8 & 35 & 0.59 & 0.0007 & 0.516 & 6.2 & 0.8 & -0.4 & 26 & 0.8 \\
\hline $\begin{array}{l}\text { Domain } 2 \\
\text { (D2) }\end{array}$ & $\begin{array}{l}\text { Mineralised } \\
\text { argillite/sheared }\end{array}$ & 0.9 & 78 & 2,950 & 72.8 & 6 & -6.7 & 40 & 0.7 & 0.0013 & 0.511 & 11.6 & 1.3 & -0.07 & 29 & 0.93 \\
\hline $\begin{array}{l}\text { Domain } 3 \\
\text { (D3) }\end{array}$ & Argillite & 2.3 & 95 & 2,800 & 54.3 & 6 & -5.8 & 45 & 0.84 & 0.0022 & 0.508 & 12.1 & 5.4 & -0.32 & 39 & 1.65 \\
\hline $\begin{array}{c}\text { Domain } 4 \\
\text { (D4) }\end{array}$ & $\begin{array}{l}\text { Basalt }+ \text { Qtz/sheared } \\
\text { Ash tuff }+ \text { Qtz/sheared } \\
\text { Fault zone or dyke } \\
\text { (in ore) }\end{array}$ & $\begin{array}{c}1.3 \\
1.6-3.3\end{array}$ & 78 & 2,850 & 73.2 & 5 & -18 & 65 & 1.43 & 0.0205 & 0.502 & 46.2 & 12.8 & -1.29 & 40 & 2.83 \\
\hline $\begin{array}{l}\text { Domain } 5 \\
\text { (D5) }\end{array}$ & $\begin{array}{l}\text { Quartz feldspar } \\
\text { porphyritic dyke/sheared } \\
\text { Quartz vein } \\
\text { (mineralised)/sheared }\end{array}$ & $\begin{array}{r}12.3 \\
3.9\end{array}$ & 120 & 2,800 & 63.5 & 5 & -28 & 65 & 1.43 & 0.0205 & 0.502 & 40.1 & 19.9 & -2 & 43 & 4.01 \\
\hline $\begin{array}{l}\text { Domain } 6 \\
\text { (D6) }\end{array}$ & Dolerite dyke (in basalt) & 12.3 & 163 & 3,000 & 95.9 & -16.1 & -16.1 & 70 & 3.08 & 0.0357 & 0.501 & 70.3 & 27.3 & -1.96 & 50 & 4.63 \\
\hline $\begin{array}{l}\text { Domain } 7 \\
\text { (D7) }\end{array}$ & $\begin{array}{l}\text { Argillite quartz } \\
\text { mineralised/sheared }\end{array}$ & 13.9 & 184 & 2,950 & 72.8 & 6 & -24.2 & 45 & 0.84 & 0.0022 & 0.508 & 16.3 & 1.8 & -0.11 & 30 & 1.02 \\
\hline $\begin{array}{l}\text { Domain } 8 \\
\text { (D8) }\end{array}$ & Basalt & 14.8 & 134 & 2,800 & 72.1 & 6 & -22.5 & & 2.06 & 0.0357 & 0.501 & 52.8 & 25.4 & -2.34 & 45 & 4.82 \\
\hline $\begin{array}{l}\text { Domain } 9 \\
\text { (D9) }\end{array}$ & Ash tuff & 29.5 & 177 & 2,700 & 71.2 & 7 & -22.9 & & 2.01 & 0.0205 & 0.502 & 45 & 22.7 & -1.63 & 47 & 4.15 \\
\hline
\end{tabular}

$\mathrm{Q}=$ rock mass classification system, after Barton (1974); UCS = unconfined compressive strength; $\rho=$ density; $\mathrm{E}_{\mathrm{i}}=$ = modulus of intact rock; $\mathrm{mi}=$ Hoek-Brown material constant of intact rock; $\sigma \mathrm{i}=$ tensile strength for intact rock; GSI = geological strength index; $s$ and a = Hoek-Brown material constants; $E_{\mathrm{rm}}=$ rock mass modulus; $\sigma_{\mathrm{crm}}=$ rock mass strength; $\sigma_{\mathrm{trm}}=$ rock mass tensile strength; $\Phi=$ friction angle c-cohesion. 


\subsection{Orebody and host rocks}

The width of the mineralised portion of the argillitic area ranges on average from 0.5 to $1.5 \mathrm{~m}$. The quartz mineralised vein has a width ranging from 0.5 to $4 \mathrm{~m}$. Given the width of the orebody, it is essential that the drill and blast methods are standardised in order to minimise dilution and overbreak in stopes.

Figures 3 and 4 present typical cross-sections of the argillitic and quartz orebodies, respectively. The reef or orebody width can be visualised by the location of the development drives. The ore drives are usually under geological control and only in rare circumstances are they under survey control. Variation occurs in the orebody due to the presence of local faults that offset the ore and other geological structures such as dykes.

In the event that a dyke is intersected, the geotechnical section advises mine planning on mining through it. This area is mined on survey control.

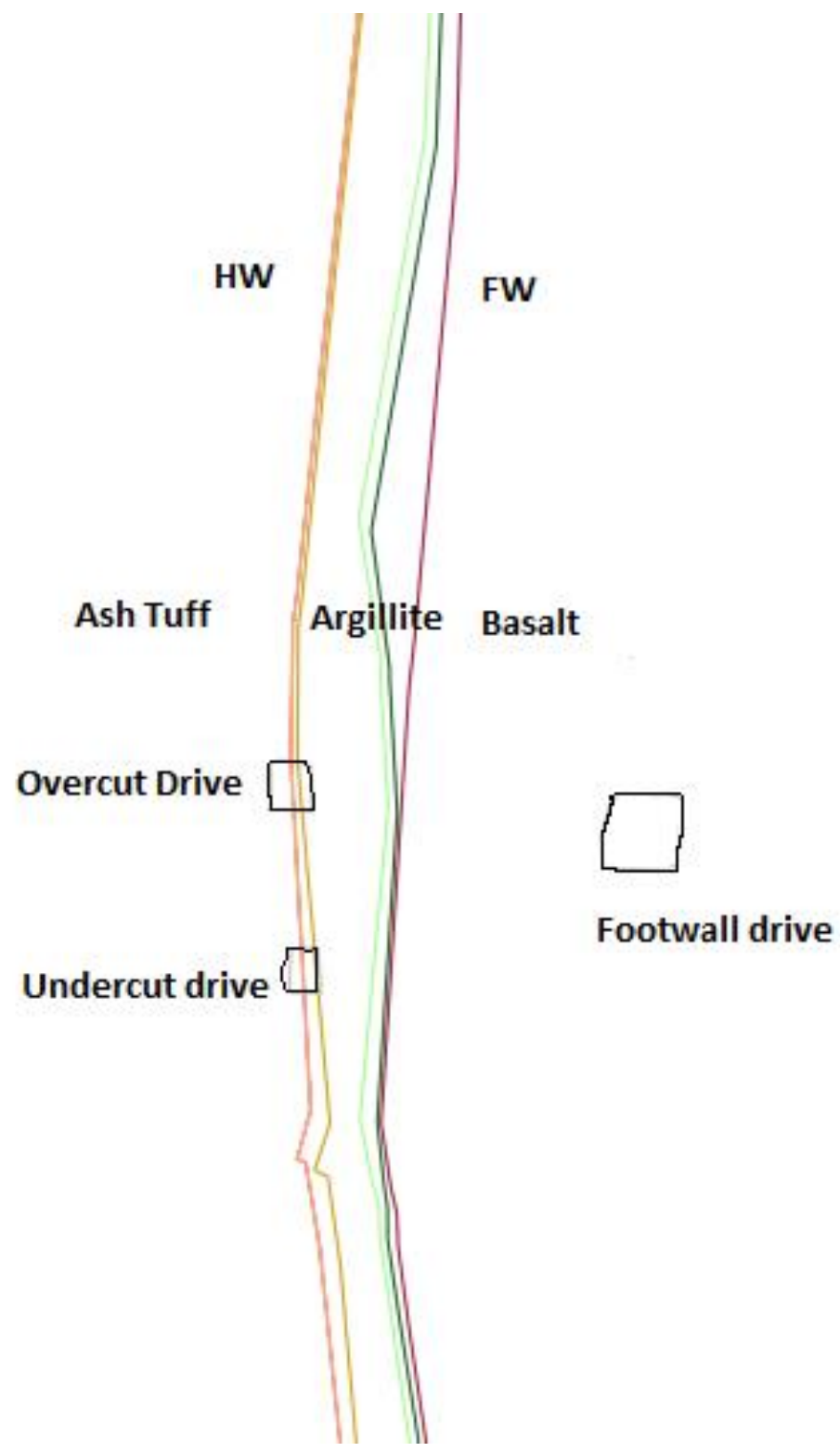

Figure 3 Cross-section orebody (argillitic) and host rocks 


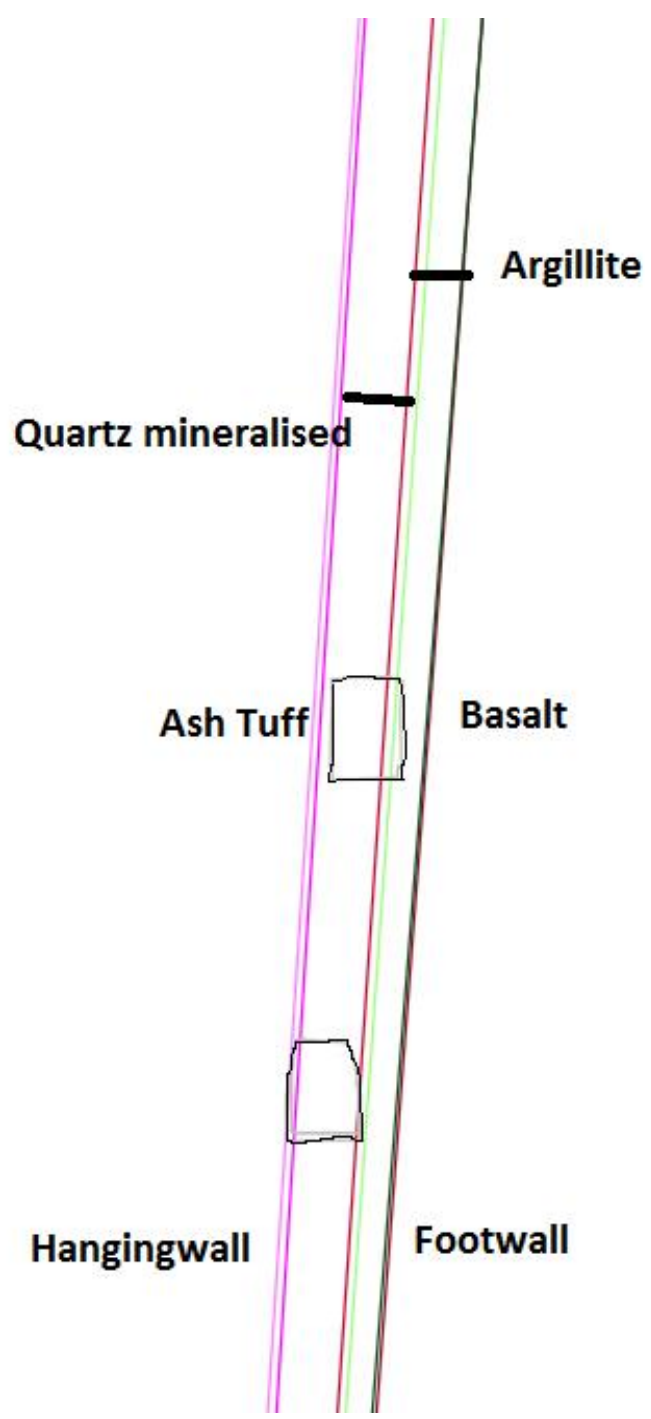

Figure 4 Cross-section of orebody with quartz

\subsection{In situ stress}

The stress gradients at Bulyanhulu are shown in Table 2. They are based on three in situ stress measurement programmes that were carried out at six different sites.

Table 2 Stress gradients assumed at Bulyanhulu Mine

\begin{tabular}{cc}
\hline Stress component & Estimate (MPa) \\
\hline$\sigma_{\mathrm{x}}$ (east-west) & $0.0319 \mathrm{Z}$ \\
$\sigma_{\mathrm{y}}$ (north-south) & $0.03625 \mathrm{Z}$ \\
$\sigma_{\mathrm{v}}$ & $0.029 \mathrm{Z}$ \\
\hline
\end{tabular}

Where $\sigma_{x}, \sigma_{y}, \sigma_{v}$ and $Z$ are minor stress, major stress, vertical stress, and depth (m below surface) respectively. 


\section{Initial stope performance}

Longhole stoping overbreak at Bulyanhulu is measured by comparing the sloughed ore tonnes and the planned tonnes. This is shown by Equation 1:

$$
\% \text { Overbreak }=\frac{\text { Ore sloughing }(\mathrm{t}) \times 100}{\text { Planned tonnes }(\mathrm{t})}
$$

Figure 5 shows the trend of the longhole stoping over the past few years. Changes are observed on a monthly basis in the overbreak results. The fluctuations depend on several major factors, including hole drill deviations, not following designs, stope wall fall-off, and incorrect application of the powder factor. There are other factors that could have caused an increase in overbreak such as high stresses in the stopes that are mined late in the sequence.

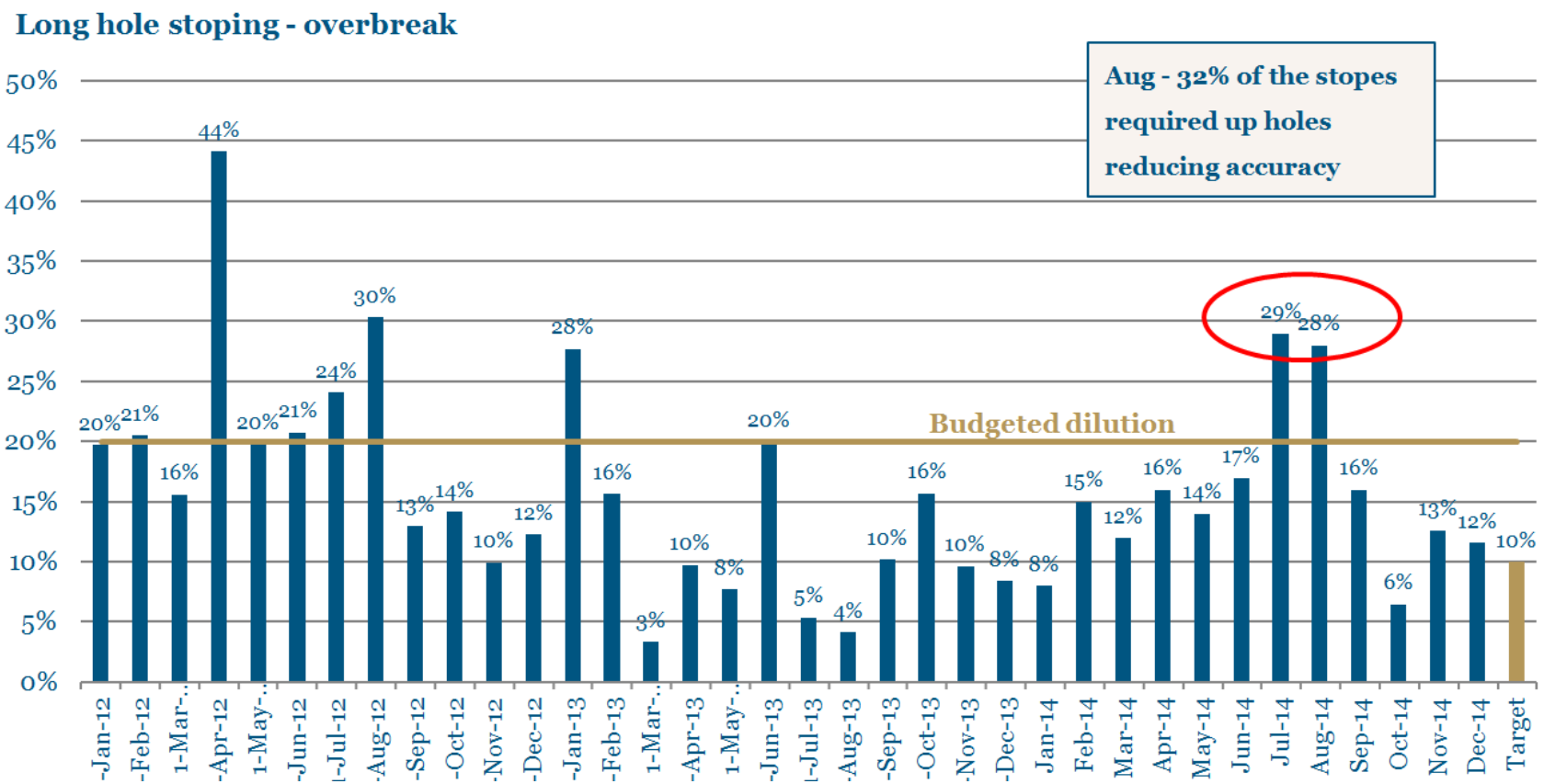

Figure 5 Historical longhole stope performance - all stopes included (paste fill support and rib pillar support)

The major contributing factors controlling stope wall overbreak were observed to be:

- Ground conditions change.

- Change of drilling from downholes to upholes to increase the accuracy.

Figure 6 shows the stability graph method (after Mathews et al. 1981; Potvin 1988; Villaescusa 2014). The graph shows back-analysed stopes for one completed stoping panel. It is important to note that this data combines both supported and unsupported stopes. 


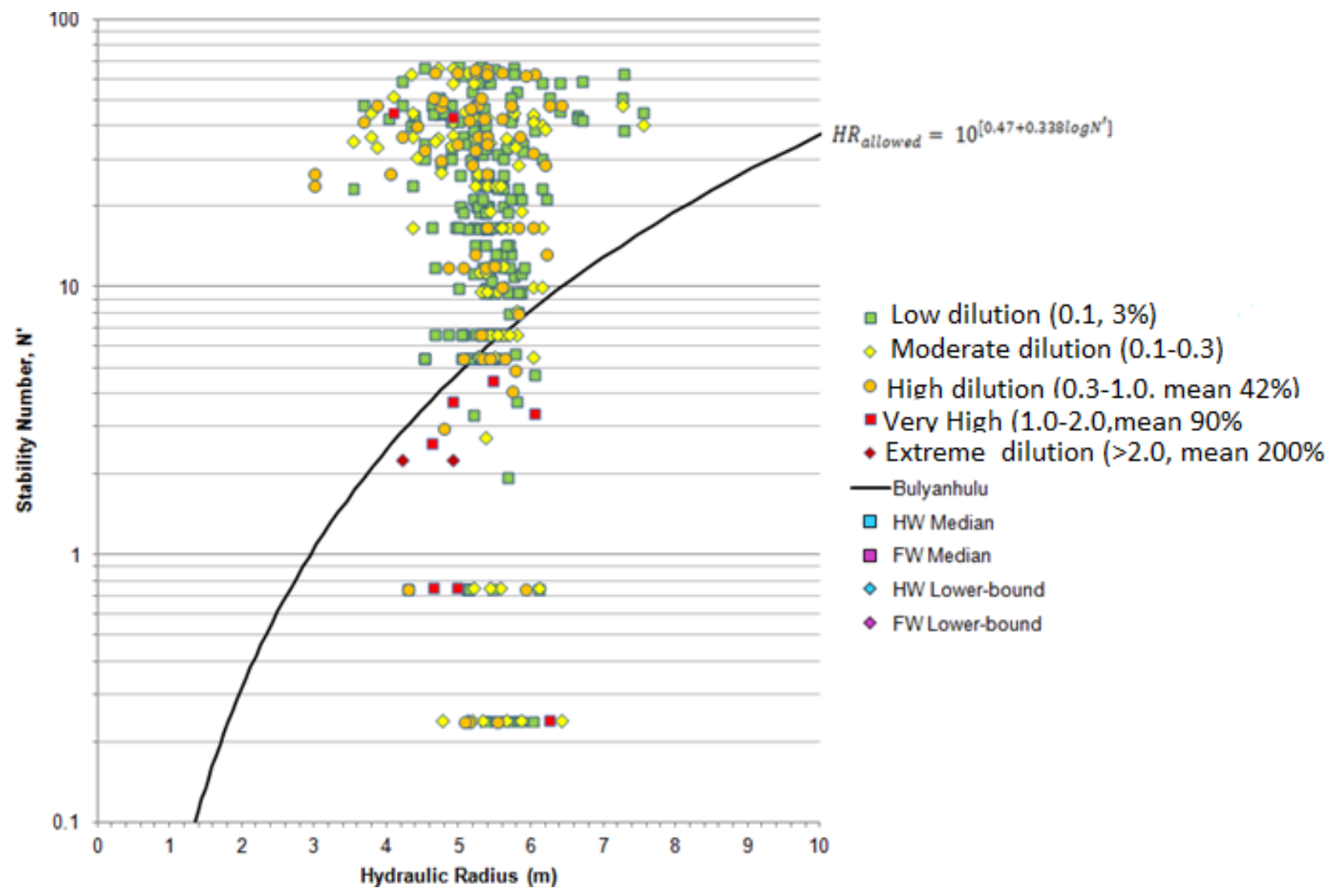

Figure 6 Stability graph determined from back-analysed data

\section{$3 \quad$ Numerical modelling}

Map 3D numerical modelling is used to estimate the stress regime in two different areas where the QA/QC improvement trial was completed. Figure 7 shows stresses in a rib pillar at 1,000 $\mathrm{m}$ below surface. Figure 8 shows the strength factor $A$ around the stope and Figure 9 shows pillar stresses at a depth of 1,260 m below surface.

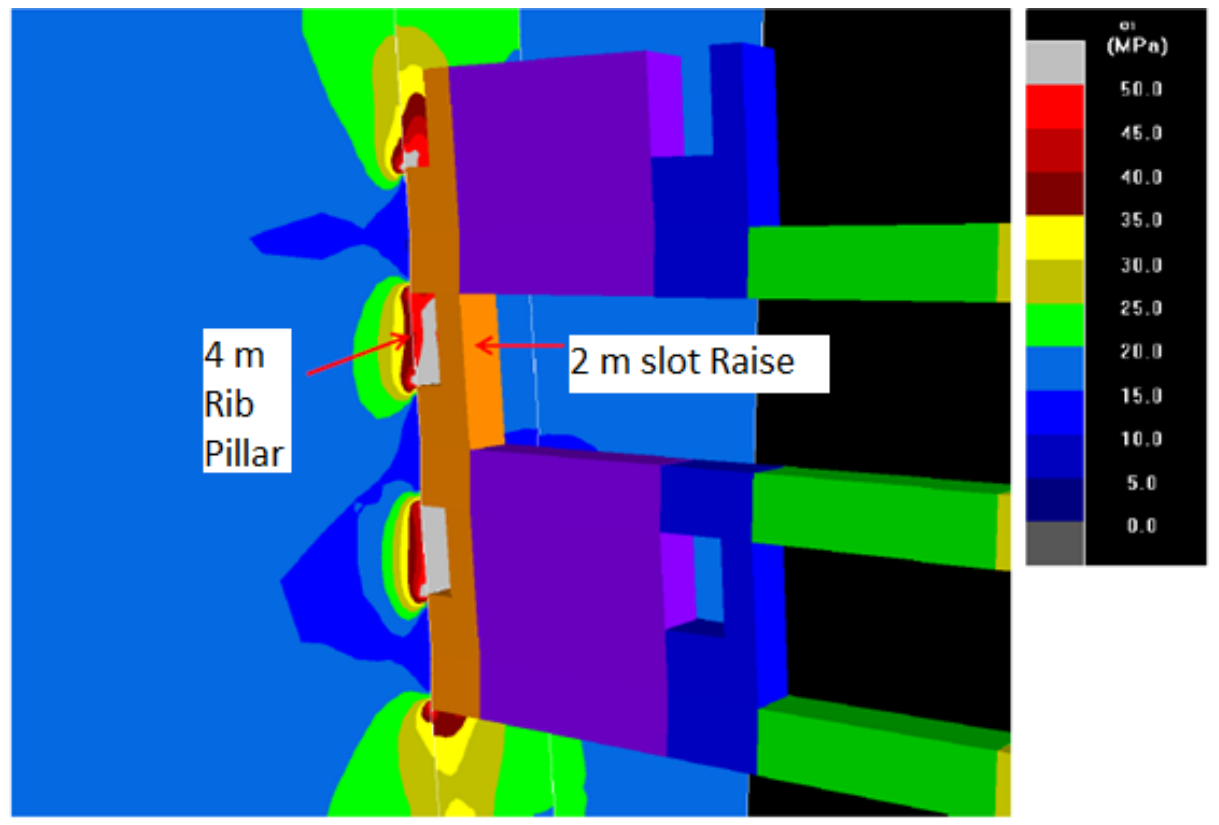

Figure 7 Numerical model results in argillite rock mass 


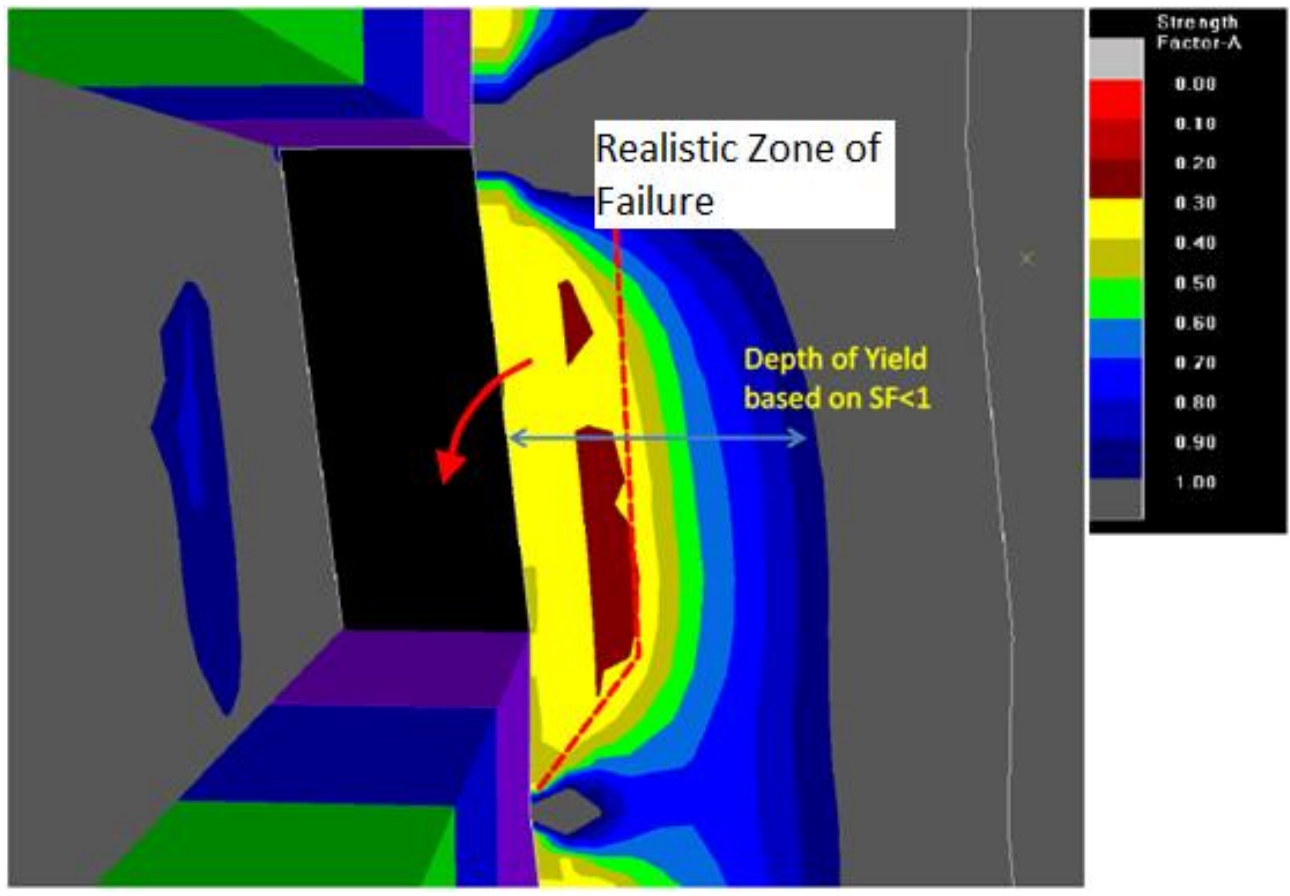

Figure 8 Hanging wall stresses (argillite)

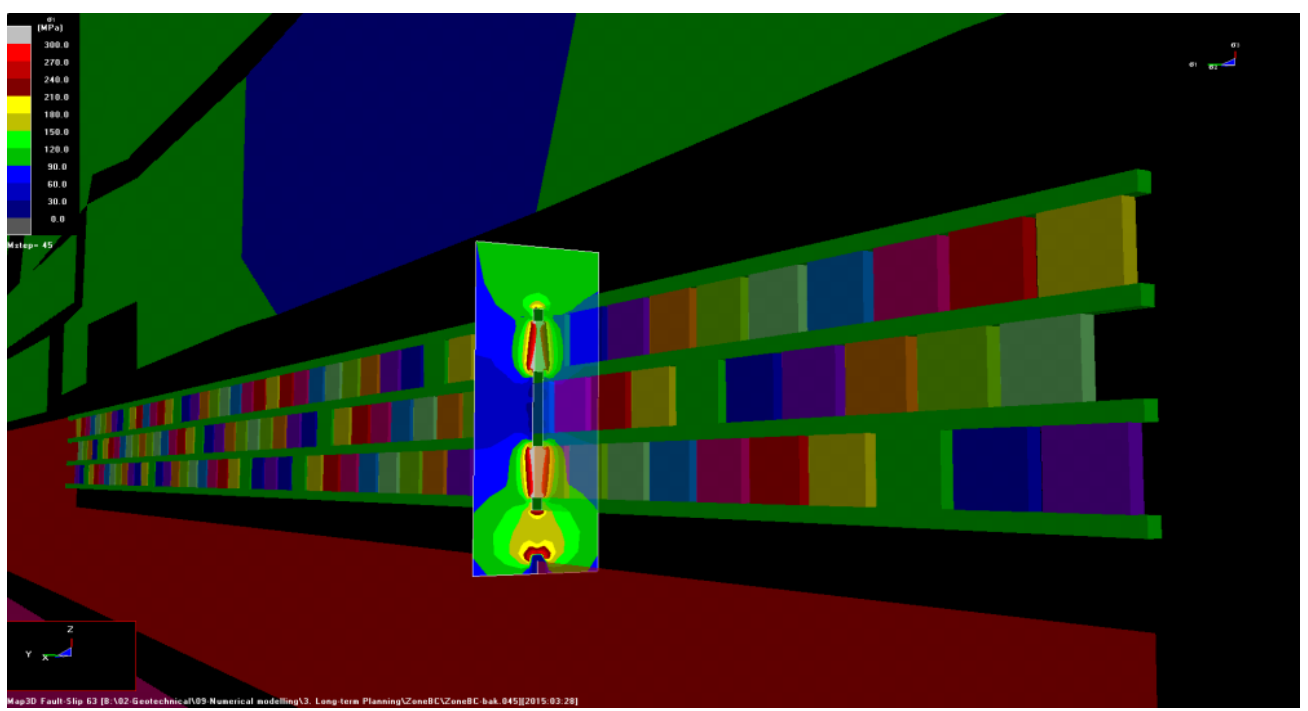

Figure 9 Pillar stress in deeper areas in mineralised quartz

\section{$4 \quad$ Drill and blast}

The typical drill and blast pattern that was employed (Figures 10 and 11) involved:

- Drilling parallel holes in all drill rings. The number of holes per ring varied according to the width of the ore drive. For cases where the orebody was wider than the ore drives, stubby holes were drilled to the full extent of the orebody to increase mining recovery.

- Delay timing used for blastholes involved a single 25 millisecond delay between holes utilising pyrotechnic detonators. The central hole in each ring was initiated first followed by sidewall holes. Subsequently, a 25 millisecond delay was utilised between the last hole blasted in a ring and the first hole blasted in the next ring. 


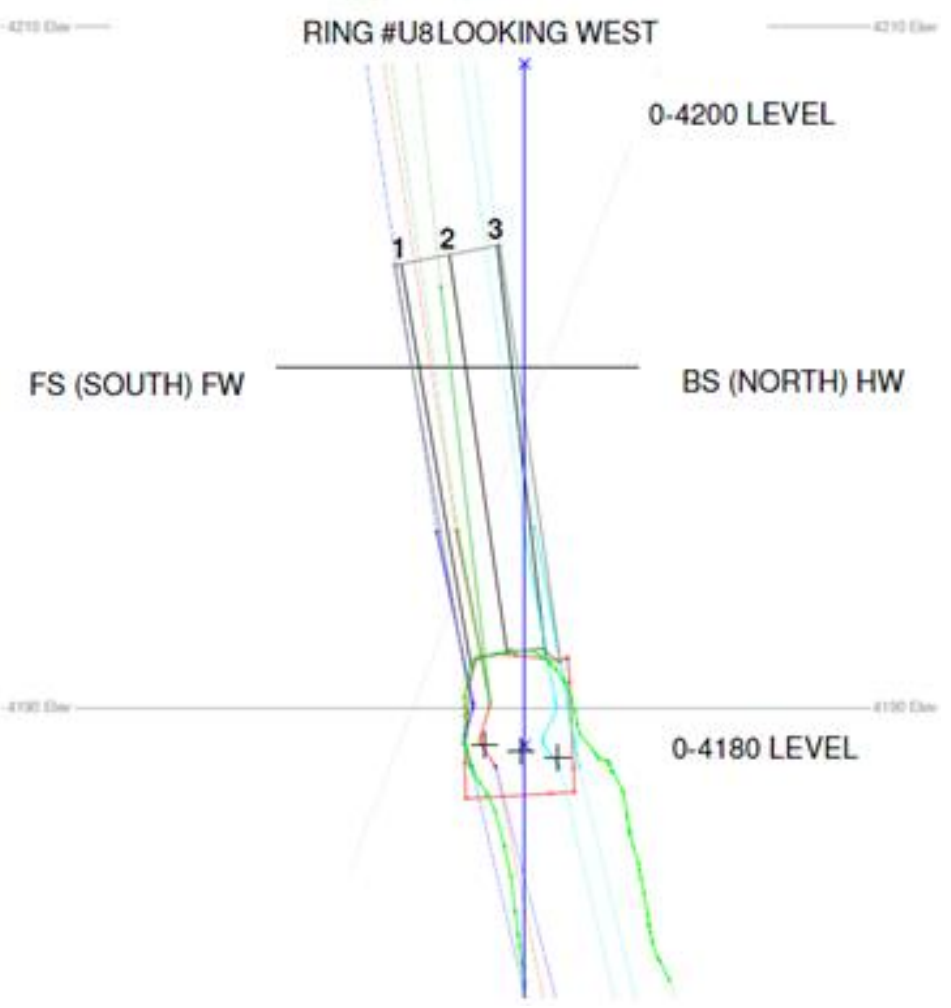

Figure 10 Section showing a typical ring design for upholes

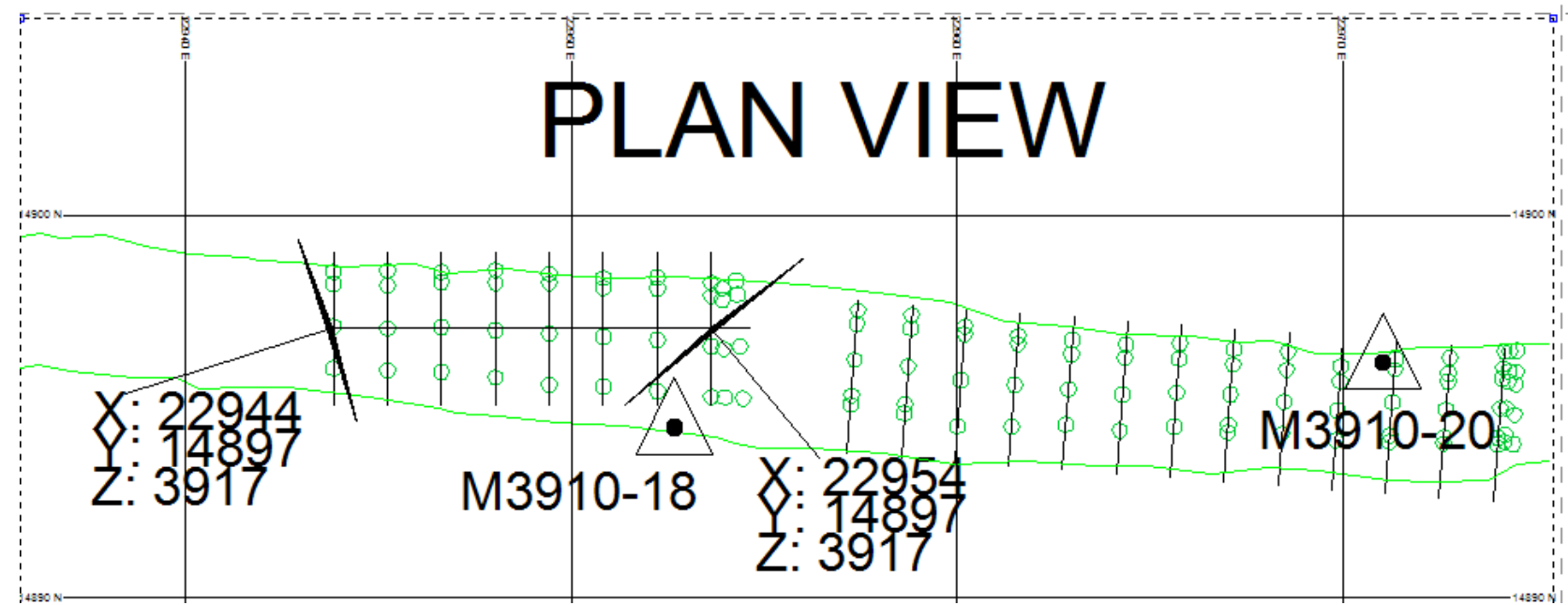

Figure 11 Typical plan views

A CMS survey is completed for all stopes and the overbreak is assessed. The geology section monitors the overbreak. Figure 12 shows a typical overbreak picked by a CMS. 


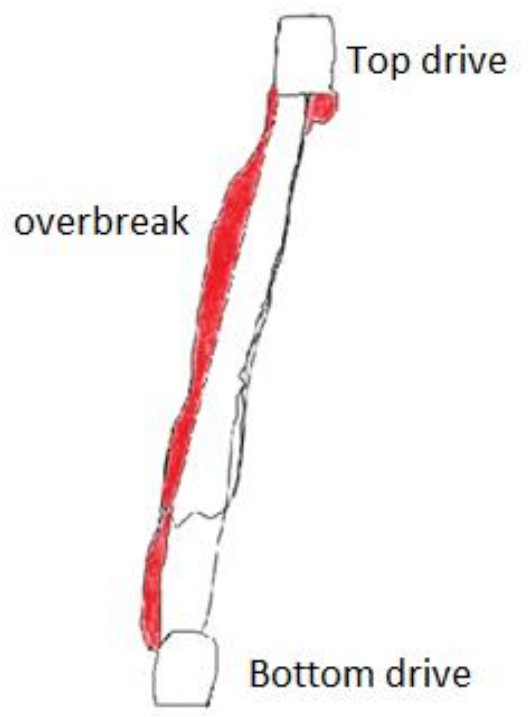

Figure 12 Overbreak picked from CMS

\section{Improvements on the drill and blast techniques}

Following an evaluation of the existing design parameters, the drill patterns were varied systematically until an improved fragmentation resulted. It is important to note that fragmentation studies are not covered in this paper. The drill pattern trialled in the initial part of the study was a 'Dice 5' pattern which also allowed for targeting the drilling to the narrow orebody width, thus reducing planned dilution.

Drilling stand-off distances from the host rocks were changed to minimise overbreak. The methodology change was through trial and observation until the desired results were achieved. They are categorised in Table 3 by explosive type and host rock.

Table 3 Initial parameters used

\begin{tabular}{cccccc}
\hline $\begin{array}{c}\text { Hole diameter } \\
(\mathbf{m m})\end{array}$ & $\begin{array}{c}\text { Burden } \\
(\mathbf{m})\end{array}$ & $\begin{array}{c}\text { Spacing } \\
(\mathbf{m})\end{array}$ & $\begin{array}{c}\text { Stand-off from wall } \\
(\mathbf{m})\end{array}$ & Explosive & Rock type \\
\hline 64 & $1.2-1.4$ & $1.5-3.0$ & 0.2 & Emulsion & Basalt/ash tuff \\
64 & $1.2-1.4$ & $1.5-3.0$ & 0.4 & Emulsion & Argillite \\
64 & $1.2-1.4$ & $1.5-3.0$ & 0.3 & ANFO & Basalt/ash tuff \\
64 & $1.2-1.4$ & $1.5-3.0$ & 0.5 & ANFO & Argillite \\
\hline
\end{tabular}

Changes were also applied on the delay timings used. The application of electronic detonators was encouraged and timings were adjusted until satisfactory results were observed. Better results were obtained when a 35 millisecond delay was used between intra-ring holes and 160 milliseconds between subsequent rings (Figure 13). 


\section{Timing Plan for Z9_3886E_3A}

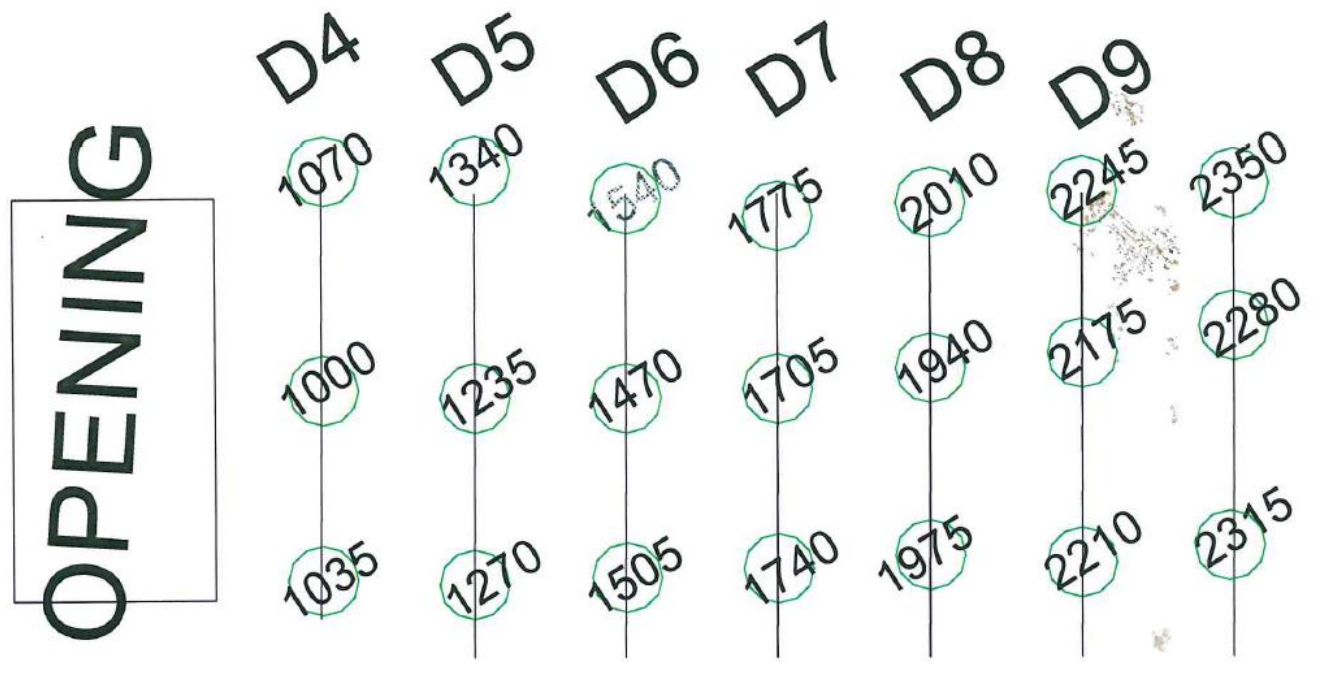

Figure 13 Delay timing for electronic detonators

Other important considerations that were part of the approach included:

- Optimising the selection of people and equipment for the improvement process - the best drill operators, charging personnel, and drill rigs were selected for initial trials.

- Improvement on QA/QC - downhole surveys were completed to measure deviation utilising a downhole camera, and task observations focused on quality drilling and charging.

- Increase in engineering stope performance and back-analysis - daily stope meetings held with drill and blast engineers, geotechnical engineers and geologists.

\section{Cable bolt installation QA/QC}

Improved plating and tensioning techniques for stope cable bolts were observed during the improvement process (Figure 14). Previously, cable bolts were often observed to be poorly installed. They were not plated and tensioned, the grout was not pumped into the hole properly, and tails were too short.

The improvements were achieved through task observations and regular reporting of these to the mining department.
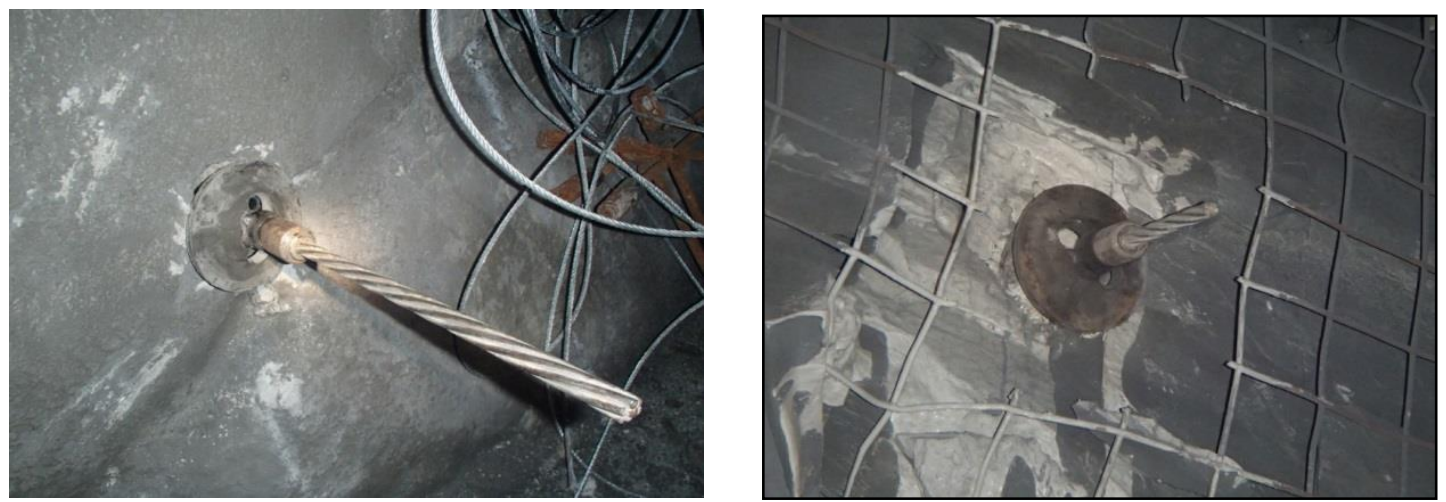

Figure 14 Cable bolt installation improvements

The improved installation practices are considered to assist in minimising stope dilution. 


\section{$7 \quad$ Improved stope performance}

Figure 15 shows the improved stope performance in the argillite with minor overbreak. An approximate $20 \%$ overall improvement is observed when compared to previous stope performance in the same ground conditions. In addition to the drill and blast improvements, the hydraulic radius was maintained at approximately $4.5 \mathrm{~m}$.
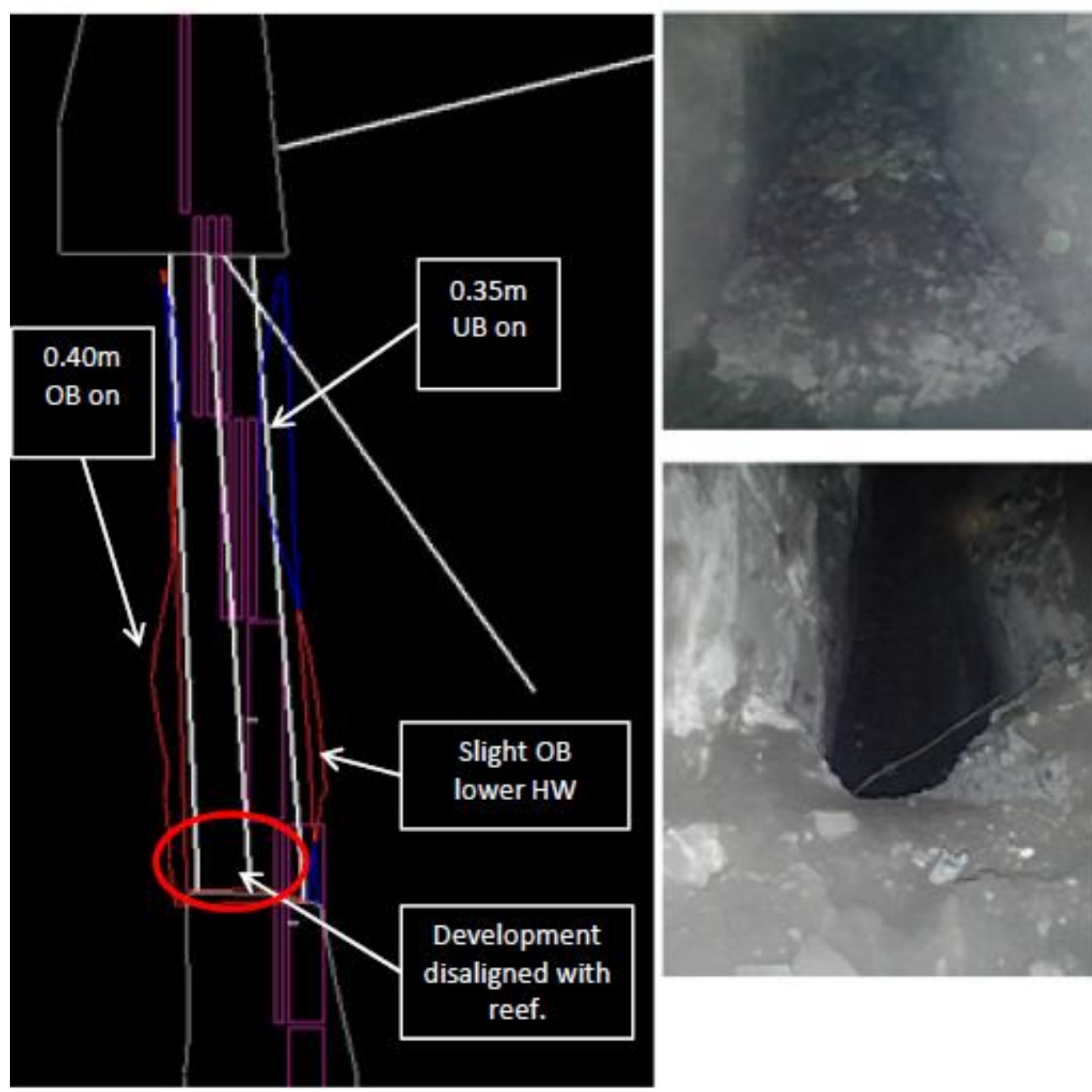

Figure 15 Improved stope stability in argillite

\section{Conclusion}

By initially changing the drill and blast practices and ensuring that the geotechnical parameters are considered in mine designs, a vast improvement was observed in the overall stope performance at Bulyanhulu. Drill and blast designs were standardised and optimised with consideration to hole diameter, burden, spacing, wall stand-off, and explosive type for each rock type. Cable bolt installation practices were improved to assist in minimising stope dilution.

Good results for stope overbreak were observed for the first stopes. Although the results are preliminary, this was a good pilot project for possible dilution reduction improvement.

\section{Acknowledgement}

The authors would like to acknowledge Acacia Mining Plc for their approval to publish this paper. 


\section{References}

Barton, N, Lien, R \& Lunde, J 1974, 'Engineering classification of rock masses for design of tunnel support', Rock Mechanics and Rock Engineering, vol. 6, no. 4, pp. 189-236.

Chamberlain, CM 2003, 'Geology and genesis of the Bulyanhulu Gold Deposit, Sukumaland Greenstone Belt, Tanzania' PhD thesis, University of London.

Mathews, KE, Hoek, E, Wyllie, DC \& Stewart, S 1981, Prediction of stable excavation spans for mining at depths below 1,000 metres in hard rock / Golder Associates, CANMET Library \& Documentation Services Division, Vancouver.

Potvin, Y 1988, 'Empirical open stope design in Canada' PhD thesis, The University of British Columbia.

Villaescusa, E 2014, Geotechnical design for sublevel open stoping, CRC Press, Boca Raton, FL. 